\title{
INTERNATIONAL ATOMIC ENERGY AGENCY
}

\begin{abstract}
HE first annual report of the Board of Governors of the International Atomic Energy Agency to the General Conference* covers the period October $23,1957-J u n e ~ 30,1958$, in which the membership of the Agency rose from twenty-six to sixty-six. Much of the work of creating the technical and administrative services needed both to implement the initial programme, which allots high priority to activities that will give the maximum benefit from the peaceful application of nuclear energy in improving the conditions and raising the standard of living of people in the under-developed areas, and to coordinate the Agency's activities with those of the United Nations and the Specialized Agencies, has been completed and operations commenced in some of the fields assigned by its statute. Excluding posts in the Division of Language Services, some two-thirds of the established posts in the Agency are in the scientific and technical divisions, and in the 111 professional staff appointed by June 30, 1958, twenty-eight nationalities were represented. Deputy directorsgeneral were appointed in December for each of the three technical departments : training and information; technical operations; and research and isotopes. Experience so far has confirmed the Preparatory Commission's expectations that initial activities in regard to the supply of materials, reactors and safeguards would consist largely of planning, collecting and exchanging information, surveys and technical advice.

The major technical assistance activity already operating is the Agency's international training programme, which embraces the training of specialists in all important peaceful applications of nuclear energy by the award of training fellowships and exchanges of scientists and experts. For these fellowships a fund of 250,000 dollars was established, and in addition 268 subsidized or fully paid fellowships for

* First Annual Report of the Board of Governors of the International Atomic Energy Agency to the General Conference covering the period from 23 October 1957 to 30 June 1958 . Pp. ii +53 . (Vienna International Atomic Energy Agency, 1958.)
\end{abstract}

training and research in institutions in their own countries were offered by member States. A field study is being made in Latin American countries to determine their requirements for training in the peaceful uses of nuclear energy and the availability of existing facilities. It is expected that the basic technical library will be functioning by the end of 1958, and the Agency's scientific and technical documentation service is already providing abstracts of scientific material and specialized bibliographies. It is also proposed to issue lists of all conferences in this field held throughout the world and to assist member States and scientific and technical organizations in planning and timing such meetings.

A provisional manual on radiation protection is planned, and an expert panel has been convened, while the collection and evaluation of data on the disposal of radioactive waste have commenced. The reactor programme will be divided into the physics and chemistry of reactors ; problems of engineering ; and production of nuclear energy. Data are being collected for an international reactor directory covering all types of power, research and training reactors. Under isotopes and research, plans are being made for forming composite isotope teams, including experts on applications of radioisotopes and radiation, to be sent on request to countries in the less-developed areas, and a survey is being made with a view of compiling an international catalogue of radioisotopes. The work of the Ageney is further displayed in its Programme and Budget for 1959*, in which an analysis of its proposed expenditure of $6 \cdot 725$ million dollars (including 550,000 dollars on scientific information and conferences, 2.575 million dollars on technical assistance and 1.050000 million dollars on regulatory activities) is accompanied by a description of the functions and programme of each of its departments.

* International Atomi. Fuergy Agener Pregramme and Budget * International Atomic Fnergy Ageney. Programme and Budget
for 1959. Pp. vii +94 . (Vienna: International Atomic Energy Agency, 1958.)

\section{NETHERLANDS-NORWEGIAN JOINT ESTABLISHMENT FOR NUCLEAR ENERGY RESEARCH}

\begin{abstract}
THE sixth annual report* of the NetherlandsNorwegian Joint Establishment for Nuclear Energy Research (J.E.N.E.R.), the joint research and training centre sponsored by the Dutch Reactor Centrum Nederland (R.C.N.) and the Norwegian Institut for Atomenergi (I.F.A.), which has now been published, describes the work of the Establishment during the period July 1, 1956--June 30, 1957. Tho governing board consists of a joint commission comprising three Dutch and three Norwegian members, and the work of the Establishment is directed by Mr. Gunnar Randars, who was appointed by the Institut for Atomenergi with the approval of the Reactor Centrum Nederland. The staff is grouped into six divisions--physies, engineering, civil engin-

* Sixth Annual Report, July 1956-June 1957, of the NetherlandsNorwegian Joint Fstablishment for Nuclear Energy Research. Pp. 31. (Kjeller, near Lillestrom: JEN ER, 1958.)
\end{abstract}

eering, chemistry, isotopes, and health physics-in addition to the administration, and during the period under review totalled 180 , of which fifty-four are classified as scientists and engineers and sixty-four as technicians and skilled workers.

The research reactor, JEEP, which is fuelled with natural uranium and moderated and cooled by heavy water and which is situated at Kjeller, was in almost continuous operation at $450 \mathrm{~kW}$. during the year, and approximately $92 \mathrm{MW}$. days of energy were released. Complete shut-downs occurred only for holidays and for the semi-annual inspection work. The Halden boiling-water reactor (HBWR) which uses heavy water, and which was designed by the Establishment, is being built by the Institut for Atomenergi and is now at an advanced stage of construction; it was expected to go critical some time during 1958. The civil engineering work has been completed; the 
workshop in the control building has been equipped; and the offices on the first floor of the building are in use. Most of the mechanical components of the reactor are being made by Norwegian firms, but the uranium fuel will be supplied by the United Kingdom Atomic Energy Authority and the heavy water by the United States Atomic Energy Commission. The reactor will be operated at low temperatures to begin with, and preliminary investigations have shown that $2 S$-aluminium withstands these low temperatures well and therefore is suitable as canning material for the initial fuel charge.

Information concerning the probable kinetics of the reactor has been obtained through void-coefficient experiments conducted by the physics division and by the use of a reactor simulator which was built specially for this purpose. The simulator consists of an analogue computer, loaned by the Norwegian Defence Research Establishment, to which has been added various units for the simulation of reactor kinetics and xenon poisoning and a multiplier circuit.

The nuclear ship-propulsion group has concentrated its attention on the use of uranium oxide - light water lattices for ship reactors. Parametric analyses of various fuel-moderator systems have been carried out, and optimization studies of reactor plant components have been made. Problems relating to both normal as well as adverse operational conditions, such as collisions at sea, groundings, fire and ex. plosion hazards, have been considered and discussed with the appropriate Norwegian maritime authorities.

In addition to the void-coefficient experiments the physics division has continued its exponential experi. ments on heavy water - natural uranium lattices which it is carrying out in eo-operation with A. B. Atomenergi at Stockholm. A report of measurements on clean lattices has been published $(J$. Nuclear Engineer. ing, 3 ; 1956) and a report on cluster type rods has been issued by A. B. Atomenergi (AEF-65). A Nonius general-purpose camera has been added to the $\mathrm{X}$-ray equipment and X-ray work has been mainly concentrated on phosphoric acid. The investigation of capture gamma circular polarization has continued and work on the gamma-spectrum of fission has been started. The health physics service of the Establishment was intensified during the period under review and the report mentions that only one member of the staff received a dose in excess of $5 \mathrm{r}$. and that 81 per cent received less than $1 \mathrm{r}$. The service controls about 150 persons.

Details are also given in the annual report of the production and shipments of radioisotopes; of the activities of the chemistry and metallurgical sections of the Establishment ; of the reports and publications published by the Establishment and members of the staff ; of the Establishment's reactor courses and of the new reactor school being opened in 1958 with a nine-week full-time postgraduate course in fundamentals of nuclear engineering; and of the personnel and accounts of the Establishment.

\section{RESEARCH AND DEVELOPMENT IN THE B.B.C.}

$\mathrm{A}^{\mathrm{N}}$

PART from the maintenance and steady improvement of a nation-wide sound and television service, the manner in which the Engineering Division of the B.B.C., and particularly of its Research and Designs Departments, continues to make technical progress, is well illustrated by the B.B.C. Engineering Division Monographs, of which Nos. 15-19 have been published during the past few months* (reference was made to Nos. $12-14$ in Nature, 181, 1046 ; 1958). These deal with a variety of subjects, from the quantitative measuring technique which is a necessary tool in the transmission and reproduction of high-quality sound to an appraisal of the results of the experiments made by the B.B.C. in colour television.

Monograph No. 15, entitled "New Equipment and Methods for the Evaluation of the Performance of Lenses for Television", outlines the photo-electric method of testing lenses and describes a new optical bench developed for the purpose. The factors affecting the quality of a television picture are discussed, and formulæ are developed on an experimental basis for an index of quality for both monochrome and colour television.

The analysis and measurement of the extremes of sound programme-levels are dealt with in Monograph

* B.B.C. Engineering Monographs. No. 15: New Equipment and Methods for the Evaluation of the Performances of Lenses for Television. By W. N. Sproson. Pp 16. No. 16: Analysis and Measurement of Programme Levels. Part 1 . Investigation of Extreme Values of Sound Pressure. By D. E. L. Shorter and W. I. Manson. Part 2: A By E. R. Wigan. Pp. 31. No. 17: The Design of a Linear PhaseShift Low-Pass Filter. By J. E. Weaver. Pp. 23. No. 18: The B.B.C. Colour Television Tests-an Appraisal of Results. 18 ; The Sproson, S. N. Watson and M. Campbell. Pp. 39. No. 19: A V.H.F. Television Link for Outside Broadcasts. By K. C. Quinton. Pp. 20 (London: British Broadcasting Corporation, 1957 and 1958.) 5s. each.
No. 16 in two parts: (1) "Investigation of Extreme Values of Sound Pressure", by D. E. L. Shorter and W. I. Manson ; and (2) "A Description of an Optical Instrument for Monitoring Sound Signals", by E. R. Wigan. An optical projection type of instrument has been developed, the range of indication of which is sufficient to deal with the most difficult programme material. While the instrument has a limited field of application to sound broadcasting, it has obvious advantages for the control of sound channels in television.

"The Design of a Linear Phase-Shift Low-Pass Filter", by L. E. Weaver (Monograph No. 17), describes the theoretical and practical details of the design of a very linear phase-shift low-pass filter intended to remove noise and other irrelevant information above approximately $3 \mathrm{Mc} / \mathrm{s}$. from the output of a television camera control unit. A "Note on Random Fluctuation Noise in Image Orthicon Camera Tubes", by R. D. A. Maurice, is appended and revises some of the conclusions in an earlier monograph on the distribution of noise over the grey scale of a picture.

Monograph No. 18 forms an interesting highlight in the series under review and is entitled "The B.B.C. Colour Television Tests : an Appraisal of Results", by W. N. Sproson, S. N. Watson and M. Campbell. This describes the results of field trials condueted during 1955-57 in viewers' homes by the Research and Designs Departments of the Corporation after preliminary experiments and the development of suitable receivers in the laboratory. Since the tests were completed, a further series was carried out during 1957-58 and the results are now being analysed. 